\title{
Analisis Pengendalian Biaya Operasional Dalam Meningkatkan Laba Pada PT. Cakra Berlian Utama Muara Enim
}

\author{
Heryati ${ }^{1}$, Asmawati ${ }^{2}$ \\ ${ }^{1}$ Fakultas Ekonomi Universitas PGRI Palembang, yatiheryati67yahoo.com \\ ${ }^{2}$ Fakultas Ekonomi Universitas PGRI Palembang, asmawatimz41@gmail.com
}

\begin{abstract}
The formulation in this study is how to control operational costs in increasing profits at PT. The Main Diamond Chakra of Muara Enim. The goal is to find out whether operational cost control is running well or not. This study uses a qualitative research method that is interactive with valid data, so that there is data analyzed to get meaning, then the data used is secondary data with data collection techniques through documentation. Based on the results of the analysis carried out that in the two periods the realization and budget carried out by the company in 2018 and 2019 was better because in that year the realization of operational costs was not greater than the budget made.
\end{abstract}

Keywords: Control, Operational Costs

\begin{abstract}
ABSTRAK
Rumusan dalam penelitian ini adalah bagaimanakah pengendalian biaya operasional dalam meningkatkan laba pada PT. Cakra Berlian Utama Muara Enim. Tujuannya untuk mengetahui apakah pengendalian biaya operasional sudah berjalan dengan baik atau tidak. Penelitian ini menggunakan metode penelitian kualitatif yang bersifat interaktif dengan data yang valid, agar supaya ada data yang dianalisis memperoleh makna, maka data yang digunakan yaitu data sekunder dengan teknik pengumpulan data melalui dokumentasi. Berdasarkan hasil analisis yang dilakukan bahwa pada dua periode tersebut realisasi dan anggaran yang dilakukan oleh perusahaan pada tahun 2018 dan 2019 lebih baik karena pada tahun tersebut realisasi biaya operasional tidak lebih besar dari pada anggaran yang dibuat.
\end{abstract}

Kata kunci : Pengendalian, Biaya Operasional

\section{A. PENDAHULUAN}

Sebuah perusahaan pada prinsipnya mempunyai tujuan untuk memperoleh laba, dari hasil laba yang diperolehnya sudah tentu perusahaan dituntut untuk meningkatkan kinerjanya agar perusahaan dapat terus berkembang dan dapat diperhitungkan keberadaanya, namun dalam menjalankan kegiatan operasionalnya harus memperhatikan pengendalian biaya operasional dalam rangka meningkatkan laba. Pengendalian sangat penting, karena pengendalian merupakan proses penentuan, apa yang harus dicapai yaitu standar, apa yang sedang dilakukan yaitu pelaksanaan dan apabila perlu melakukan perbaikan-perbaikan, sehingga pelaksanaan sesuai dengan rencana yaitu sesuai dengan standar. Perusahaan dalam kegiatan operasional harus melakukan pengendalian, salah satu yang harus dilakukan pengendalian adalah biaya operasional. Biaya operasional merupakan pengorbanan sumber ekonomis yang diukur dalam satuan uang yang telah terjadi atau kemungkinan akan terjadi untuk mencapai tujuan tertentu. Dengan adanya pengendalian yang efektif yang sistematis dari biaya operasional tersebut dapat diatasi dengan baik. 
Salah satu upaya perusahaan untuk mendapatkan laba yang maksimal yaitu dengan melakukan pengendalian biaya operasional. Meningkatkan laba yang dihasilkan suatu perusahaan sangat dipengaruhi oleh jumlah biaya operasional yang dikeluarkan perusahaan itu sendiri, supaya tujuan tersebut dapat berjalan dengan baik. Maka perlu dilakukan pengendalian terhadap biaya operasional dengan harapan dapat mengurangi pemborosan terhadap penggunaan biaya perusahaan.

PT. Cakra Berlian Utama Muara Enim merupakan salah satu cabang perusahaan semen. Dalam rangka meningkatkan laba untuk itu harus ada strategi yang dirancang tepat pada sasaran yang dituju dan juga dibutuhkan suatu analisa maupun kajian dari strategiyang telah dijalankan secara bertahap guna mencapai hasil yang maksimal. Biaya operasional tentunya mempengaruhi laba yang ingin dicapai oleh perusahaan berdasarkan penjualan yang dilakukan dan biaya operasional yang dikeluarkan oleh perusahaan dalam melakukan kegiatan perusahaan.

Laba suatu perusahaan memperoleh pendapatan dari kegiatan penjualan sebagai selisih dari seluruhan usaha yang didalam usaha itu terdapat biaya yang dikeluarkan untuk proses penjualan selama periode tertentu dalam perusahaan itu sendiri.namun ada kalanya realisasi biaya opeasional melebihi biaya operasional yang sudah ditetapkan yang mana hal ini sangat berpengaruh pada pencapaian laba.

Agar tidak terjadinya penyimpangan dana usaha yaitu realisasi biaya yang dikeluarkan lebih besar dari jumlah biaya yang dianggarkan sehingga dapat mengurangi laba usaha perusahaan. Maka perlu adanya pengendalian biaya operasional yang harus dilakukan oleh pihak manajemen PT. Cakra Berlian Utama Muara Enim. Setelah diadakan pengendalian biaya operasional ini diharapkan dapat menekan tingkat biaya yang dikeluarkan serta dapat meningkatkan laba perusahaan.

\section{B. KAJIAN TEORI}

\section{1) Pengertian biaya}

Seluruh kegiatan perusahaan baik dalam produksi, pemasaran ataupun administrasi pasti berkaitan dengan biaya. Biaya jugaberkaitan dengan semua jenis usaha, baik untuk usaha manufaktur maupun untuk pelayanan.

Seiring dengan semakin berkembangnya ilmu pengetahuan, banyak dari para ahli yang mendefinisikan tentang biaya diantara menurut : Wasilah (2012:22) Biaya adalah pengeluaran-pengeluaran atau nilai pengorbanan untuk memperoleh barang atau jasa berguna untuk masa yang akan datang atau mempunyai manfaat melebihi satu periode akuntansi.

Menurut Carter (2012:30) biaya adalah sebagai suatu nilai tukar, pengeluaran, atau pengorbanan yang dilakukan untuk menjamin perolehan manfaat. Menurut Mulyadi (2015:23) akuntansi biaya adalah pengorbanan sumber ekonomi, yang diukur dalam satuan uang, yang telah terjadi atau yang kemungkinan akan terjadi untuk tujuan tertentu.

Menurut Bustami dkk (2010:12) biaya adalah pengorbanan sumber ekonomis yang diukur dalam satuan uang yang telah terjadi atau kemungkinan akan terjadi untuk mencapai tujuan tertentu. Dan digolongkan sebagai aktiva yang di masukkan di dalam neraca.

\section{2) Biaya Operasional}

Biaya operasional merupakan aspek yang tidak dapat dipisahkan dalam 
keberlangsungan unit usaha suatu perushaan, di dalam kegiatan usahanya perusahaan diharuskan untuk mengeluarkan biaya operasional demi menunjang usaha yang sedang dijalankannya demi mencapai tujuan yang diinginkan, selain itu dalam keberlangsungan usahanya perlu dilakukan pengendalian terhadap biaya operasional itu sendiri agar biaya operasional tersebut berjalan dengan efektif dan sesuia dengan kebutuhan perusahaan.

Secara umum dalam menjalankan kegiatan perusahaan terdapat pengeluaran yang harus dikeluarkan oleh perusahaan salah satunya biaya operasional. Setiap perusahaan pasti memiliki pengeluaran operasional karena hal tersebut mutlak bagi suatu perusahaan dalam menjalankan usahanya.

Sejak dulu banyak para ahli yang mendifinisikan tentang biaya operasional diantaranya Mulyadi (2015:10) yang menyatakan bahwa biaya merupakan objek yang dicatat, digolongankan, diringkas, dan disajikan oleh akuntansi biaya. Sedangkan menurut Bustami dan Nurlela (2011:07) yang menyatakan bahwa biaya operasional pengorbanan sumber ekonomis yang diukur dalam satuan uang yang telah terjadi atau kemungkinan akan terjadi untuk mencapai tujuan tertentu.

\section{3) Pengendalian Biaya Operasional}

Biaya operasional merupakan aspek yang dapat dipisahkan dalam keberlangsungan unit usaha suatu perusahaan, didalam kegiatan usahanya. Perusahaan diharuskan untuk mengeluarkan biaya operasional demi meningkatkan usaha yang sedang dijalankan untuk mencapai tujuan yang diinginkan. Selain itu dalam keberlangsungan usahanya perlu dilakukan pengendalian terhadap biaya operasional tersebut berjalan dengan efektif dan sesuai kebutuhan perusahaan.

Menurut Bustami dan Nurlela (2010:07) yang menyatakan bahwa biaya operasional adalah pengorbanan sumber ekonomis yang diukur dalam satuan uang yang terjadi atau kemungkinan akan terjadi untuk mencapai tujuan tertentu.

Sedangkan biaya operasional merupakan biaya yang masa pakainya belum habis yang telah dicatat dan digolongkan kedalam suatu pengorbanan sumber ekonomis yang diukur dalam satuan uang untuk mencapai tujuan tertentu. Dengan demikan, biaya operasional termasuk aktifitas organisasi dalam mengendlikan biaya operasional untuk mendapatkan tujuan yang dihadapkan.

\section{4) Anggaran (Budget)}

Didalam melaksanakan kegiatan usahanya, setiap perusahaan selalu dihadapkan pada masa yang penuh dengan ketidakpastian, sehingga akan menimbulkan masalah pemilihan dari berbagai alternatif kebijakan yang akan ditempuhnya dalam melaksanakan kegiatan usahanya tersebut. Disamping itu, dalam melaksanakan kebijakan yang telah diputuskan tersebut, perlu adanya suatu alat untuk mengkordinasikan semua kegiatan agar dapat berjalan secara resmi dan terkendali. Dengan kata lain anggaran akan sangat bermanfaat untuk mensinergikan seluruh sumber dana dayayang ada pada suatu perusahaan dalam rangka mencapai tujuan yang diinginkan oleh perusahaan yaitu memperoleh laba yang semaksimal mungkin.

Menurut Carter (2012:13) anggaran adalah penyataan yang terkuantitatif dan tertulis dari rencana manajemen. Seluruh tingkat manajemen sebaiknya terlibat dalam membuatnya. Anggaran yang dapat dilaksanakan meningkatkankoordinasi dari perkerja, klarifikasi kebijakan, kristalisasi rencana.

Menurut Islahuzzaman (2012:28) anggaran adalah suatu rencana tindakan yang diusulkan oleh manajemen secara terinci yang dinyatakan secara formal dalam 
angka-angka dan sistematis dari seluruh kegiatan yang akan dilakukan dalam perencanaan, koordinasi dan pengandilan dalam ukuran kuantitatif, biasanya dalam satuan uang, untuk menunjukkan perolehan dan penggunaan sumber-sumber suatu organisasi yang akan digunakan sebagai pedoman pelaksanaan kegiatan dalam jangka waktu tertentu, biasanya satu tahun.

Dari beberapa pengertian manurut para ahli diatas diatas, maka anggaran adalah suatu rencana yang dilakukan oleh pihak manajemen perusahaan dalam menyusun biaya yang akan dikeluarkan pada periode usaha yang akan berjalan dimasa yang akan datang dalam waktu yang telah ditentukan.

\section{5) Pengertian Laba}

Menurut Islahuzzaman (2012:238) laba adalah selisih total pendapatan (revenue) dikurangi biaya-biaya (expense) dari kegiatan usaha perusahaan yang diperoleh selama periode tertentu. Menurut Ahmad Riahi (2011:226) laba adalah hal yang mendasar dan penting dari laporan keuangan dan memiliki banyak kegunaan diberbagai konteks. Sedangkan menurut Sutopo (2014:35) laba peningkatan nilai pada ekuitas yang diakibatkan oleh seluruh transaksi yang terjadi dalam suatu periode.

Berdasarkan defenisi para ahli diatas, laba adalah sejauh dimana suatu perusahaan memperoleh pendapatan dari kegiatan penjualan sebagai selisih dari seluruhan usaha yang didalam usaha itu terdapat biaya yang dikeluarkan untuk proses penjualan selama periode tertentu.

\section{METODE PENELITIAN}

Menurut Sugiyono (2017:49) secara umum metode penelitian diartikan sebagai cara ilmiah untuk mendapatkan data dengan tujuan dan kegunaan tertentu. Metode penelitian adalah cara ilmiah untuk mendapatkan data yang valid dengan tujuan dapat ditemukan, dikembangkan dan dibuktikan, suatu pengetahuan tertentu sehingga pada gilirannya digunakan untuk memahami, memecahkan dan mengantisipasi masalah dalam bidang tertentu. Terdapat dua jenis metode penelitian yang digunakan untuk menganalisis data yaitu :

1. Metode penelitian kualitatif

Metode penelitian kualitatif yaitu metode-metode penelitian yang berdasarkan pada filsafat ketidak pastian digunakan untuk meneliti pada kondisi objek yang alamiah (sebagai lawannya adalah experimen).

2. Metode Penelitian Kuantitatif

Metode penelitian dapat diartikan sebagai metode penelitian yang berlandaskan pada kepastian (data), digunakan untuk meneliti pada populasi atau sampel tertentu.

Analisa data yang digunakan dalam penelitian ini adalah metode data kualitatif yaitu dengan mengetahui pengendian biaya operasional untuk meningkatkan laba yang dihasilkan pada PT. Cakra Berlian Utama Muara Enim dan data digunakan menghitung tingkat laba efisiensi.

\section{POPULASI DAN SAMPEL}

1) Populasi

Menurut Anwar (2014:87) Populasi adalah seluruh kumpulan elemen yang menunjukkan ciri-ciri tertentu yang dapat digunakan untuk mempunyai kualitas dan karakteristik tertentu yang ditetapkan oleh penelitian untuk dipelajari dan kemudian 
ditarik kesimpulannya. Populasi dalam penelitian ini adalah pengendalian biaya operasional untuk meningkatkan laba pada PT. Cakra Berlian Utama Muara Enim.

2) Sampel

Menurut Anwar (2014:88) Sampel adalah bagian dari jumlah dan karakteristik yang dimiliki oleh populasi tersebut, untuk itu sampel dalam penelitian ini adalah pengendalian biaya operasional dengan penyusunan pengendalian biaya laba rugi tahun 2018 dan 2019.

\section{E. TEKNIK PENGUMPULAN DATA}

Teknik yang digunakan untuk memperoleh data keterangan guna pemecahan masalah dalam penelitian ini adalah dengan cara dokumentasi yaitu mengadakan penelitian secara langsung terhadap objek penelitian.

Teknik dokumentasi yaitu teknik yang digunakan untuk mencari hal-hal atau variabel yang berupa catatan, transkip, buku, agenda, dan lain-lain sebagainya untuk mendapatkan data yang diperlukan seperti anggaran, realisasi anggaran pendapatan dan biaya operasional, dan laporan keuangan bagi peneliti menggunakan arsip-arsip yang ada diperusahaan untuk dipergunakan dalam penelitian.

\section{F. TEKNIK ANALISIS DATA}

Menurut Anwar (2014:115) teknik analisis data adalah mendeskripsikan teknik analisis apa yang akan digunakan untuk menganalisis data yang telah dikumpulkan untuk kemudian dapat memberikan interpretasi dan pengelolahan data dimaksud untuk menjawab yang telah dirumuskan.

Berdasarkan teori yang dikemukakan diatas dalam suatu penelitian terdapat dua metode, yaitu : metode analisa deskriptif dan analisa kualitatif. Teknik analisa data yang digunakan dalam penelitian ini menggunakan metode analisa deskriptif kuantitatif yaitu salah satu pendekatan yang digunakan untuk menganalisa data-data yang diperoleh untuk dihitung oleh peneliti melalui teknik analisa yang telah ditentukan. Hal ini dilakukan agar terciptanya efesiensi biaya operasional yang dikeluarkan perusahaan.

Untuk menganalisa pengendalian biaya operasional dalam upaya meningkatkan laba yang dihasilkan oleh PT. Cakra Berlian Utama Muara Enim adalah sebagai berikut :

1) Analisa Varians

Varians adalah perbedaan antara jumlah yang didasarkan pada hasil aktual dan jumlah yang dianggarkan merupakan acuan untuk melakukan perbandingan. Setiap varians merupakan suatu sinyal yang sebaiknya didentifikasi dan dianalisa. Suatu varians dapat disebabakan oleh kejadian acak yang tidak diharapkan terulang kembali, masalah sistematis yang dapat diperbaiki, atau standar yang tidak tepat. Misalnya jika proses manufaktur berubah, maka satandar fisik juga mungkin berubah.

Ada dua jenis varians, yakni :

$>$ Varians yang mengutungkan adalah varians yang memiliki pengaruh meningkatkan laba operasi relatif terhadap jumlah yang dianggarkan.

$>$ Varians yang tidak mengutungkan adalah varians yang memiliki pengaruh menurukan laba operasi relatif terhadap jumlah yang dianggarkan.

2) BOPO (Biaya Operasional Pendapatan Operasional)

Analisa ini dipakai untuk membandingkan biaya operasional dibagi dengan pendapatan lalu dikali dengan $100 \%$ sehingga menghasilkan persentase laba yang 
diperoleh perusahaan dalam suatu periode.

Rumus yang digunakan :

$$
\text { BOPO }=\frac{\text { Biaya Operasional }}{\text { Pendapatan }} \times 100 \%
$$

\section{G. HASIL PENELITIAN DAN PEMBAHASAN}

Laporan keuangan merupakan media penting dalam proses pengambilankeputusan ekonomis, laporan keuangan juga merupakan media yang sering dipakai guna meneliti kondisi kesehatan sebuah perusahaan dimana laporan keuangan ini menyediakan infomasi yang menyangkut posisi keuangan, kinerja serta perubahan posisi keuangan suatu perusahaan yang bermanfaat bagi sejumlah pemakai dalam pengambilan keputusan.

Laporan laba rugi merupakan bagian dari laporan suatu perusahaan yang dihasilkan pada suatu periode akuntansi yang menjabarkan unsur-unsur pendapatan dari beban perusahaan sehingga menghasilkan suatu laba atau rugi bersih. Laporan laba rugi pada PT. Cakra Berlian Utama Muara Enim menunjukkan kinerja pada perusahaan tersebut dalam menjalankan usahanya. Pengendalian biaya operasional perlu dilakukan untuk menjaga kestabilan biaya yang dikeluarkan sehingga laba yang dihasilkan perusahaan dapat sesuai dengan apa yang diharapkan perusahaan sehingga keberlangsungan dan kemajuan perusahaan dapat bertahan dan semakin berkembang.

Melalui laporan laba rugi pada PT. Cakra Berlian Utama Muara Enim dari tahun 2018 sampai 2019. Maka peneliti akan melakukan analisa terhadap biaya operasional perusahaan untuk menilai pengendalian biaya yang dilakukan perusahaan dalam tujuannya meningkatkan laba usaha. Data yang digunakan dalam analisa ini adalah laporan laba rugi, anggaran biaya opersional dan realisasi biaya operasional PT. Cakra Berlian Utama Muara Enim dari Tahun 2018 dan 2019, untuk melihat lebih jelas akan dikaji secara rinci sebagai berikut yang dikelompokkan dalam realisasi biaya pegawai, biaya administrasi dan pemasaran, biaya umum, biaya penyusutan, dan biaya lain-lain

Berdasarkan hasil analisis biaya operasional terhadap laba rugi tahun 2018 sampai tahun 2019 bahwa pengendalian yang dilakukan oleh pihak manajemen perusahaan sudah berjalan dengan baik namun masih ada permasalahan dalam meningkatkan laba, hal tersebut dapat dilihat dari jumlah biaya yang direalisasikan perusahaan tiap tahunnya pada jumlah yang telah dianggarkan.

Tahun 2018 jumlah keseluruhan anggaran biaya operasional sebesar Rp.198.893.835, sedangkan biaya yang direalisasikan sebesar Rp.190.306.169 jumlah tersebut menunjukan terjadinya peningkatan sebesar Rp.8.587.666 yang diartikan biaya anggaran sudah efisien. Sedangkan pada tahun 2019 jumlah keseluruhan anggaran biaya operasional sebesar Rp.288.905.551, sedangkan biaya yang direalisasikan sebesar Rp.285.210.597 jumlah tersebut menunjukan terjadinya peningkatan sebesar Rp.3.694.954 yang diartikan biaya anggaran sudah efisien.

\section{1) Analisis Pengendalian Biaya Operasional Pada PT. Cakra Berlian Utama Muara Enim}

Setelah dilakukan pengendalian terhadap biaya operasional maka diharapkan dapat meningkatkan laba usahanya. Untuk melihat sejuah mana upaya perusahaan dalam meningkatkan laba usahanya dengan melakukan pengendalian terhadap biaya operasional dengan tujuan meminimalisir biaya yang dikeluarkan sehingga 
laba yang dihasilkan dapat meningkat sesuai tujuan yang diharapkan.

Untuk melihat pengendalian dan peningkatan laba yang dihasilkan perusahaan, penulis memilih analisa deskriptif kuantitatif yaitu salah satu pendekatan yang digunakan untuk menganalisa data-data yang diperoleh untuk dihitung oleh peneliti melalui teknik analisa yang telah ditentukan.

\section{2) Metode Varians}

Teknik varians yaitu teknik yang digunakan untuk menilai pengendalian biaya operasional yang dilakukan perusahaan dengan melihat jumlah anggaran dan realisasi biaya operasional dimana jumlah realisasi biaya dikurangi jumlah anggaran biaya perusahaan sehingga dapat diketahui selisihnya.

Data yang digunakan meliputi laporan laba rugi, anggaran biaya operasional dan realisasi biaya operasional PT. Cakra Berlian Utama Muara Enim dari tahun 2018 sampai dengan 2019, berikut rincian yang dapat dijelaskan dari jumlah anggaran dan realisasi biaya perrusahaan sebagai berikut:

\section{Tabel Jumlah Anggaran dan Realisasi Biaya Operasional PT. Cakra Berlian Utama Muara Enim Periode 2018 (dalam ribuan rupiah)}

\begin{tabular}{|l|r|r|r|}
\hline \multicolumn{1}{|c|}{ Keterangan } & $\begin{array}{c}\text { Jumlah } \\
\text { anggaran biaya } \\
\text { operasional }\end{array}$ & $\begin{array}{c}\text { Jumlah } \\
\text { realisasi biaya } \\
\text { operasional }\end{array}$ & $\begin{array}{c}\text { Jumlah } \\
\text { selisih biaya } \\
\text { operasional }\end{array}$ \\
\hline Beban Penjualan & 9.579 .517 & 9.585 .117 & 54.400 \\
Pengangkutan dan distribusi & 35.421 .341 & 32.421 .344 & 2.999 .997 \\
Promosi & 4.410 .611 & 3.686 .696 & 723.915 \\
Jasa profesional & 871.291 & - & - \\
Perjalanan Dinas & 254.795 & 883.399 & 12.108 \\
Keamanan & 198.987 & 248.695 & - \\
Penyusutan & 499.138 & 190.972 & 6.100 \\
Beban Pemeliharaan & 2.987 .901 & 2.909 .891 & 8.015 \\
Telekomunikasi dan alat tulis kantor & 417.911 & 406.955 & 28.000 \\
sewa & & & 78.010 \\
Lainnya & 63.923 .617 & 64.928 .869 & 10.956 \\
Beban Adminitrasi & 12.631 .871 & 12.708 .982 & 1.005 .252 \\
Gaji, Upah dan tunjuangan & 9.981 .196 & 9.996 .196 & 77.111 \\
Perjalanan Dinas & 6.241 .817 & 5.143 .789 & 1.09 .000 \\
Sewa & 9.531 .741 & 9.453 .500 & 78.241 \\
Telekomunikasi & 5.437 .178 & 5.347 .476 & 89.702 \\
Beban Pemeliharaan & 7.413 .144 & 6.462 .244 & 950.900 \\
Penyusutan & 2.200 .214 & 2.011 .124 & 18.909 \\
Jasa Profesional & 3.375 .412 & 3.295 .312 & 80.100 \\
Sumbangan & 2.691 .148 & 1.469 .184 & 1.221 .964 \\
Listrik dan Air & 7.872 .601 & 7.227 .706 & 594.895 \\
Rapat Dinas & 2.127 .371 & 1.889 .363 & 1.939 .008 \\
Diklat dan pengadaan pegawai & 1.984 .259 & 1.496 .085 & 488.174 \\
Asuransi & 2.116 .452 & 2.016 .442 & 100.010 \\
Pembinaan Jasmani \& Rohani & 1.815 .977 & 1.715 .977 & 100.000 \\
Alat Tulis Kantor & 1.399 .606 & 1.287 .406 & 112.200 \\
Keamanan & & & \\
Penelitian dan Pengembangan & & & \\
\hline
\end{tabular}




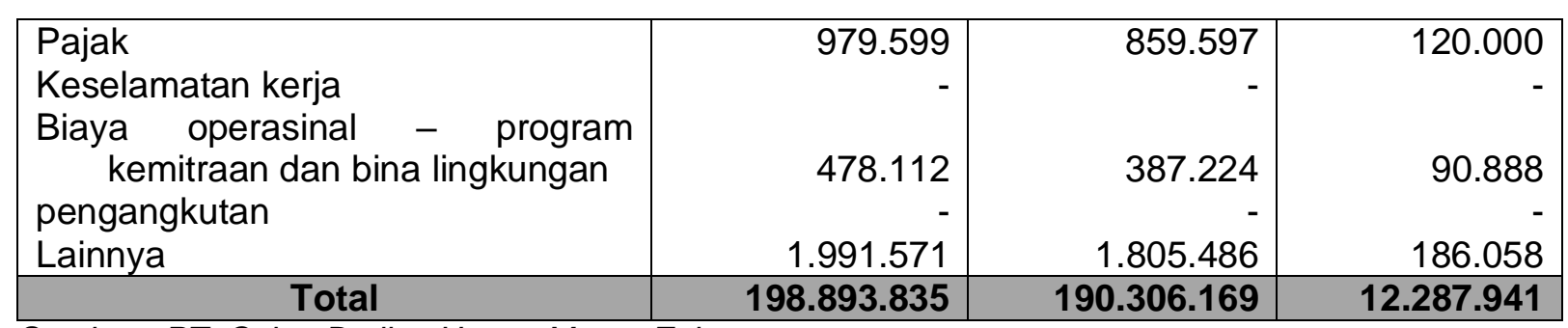

Sumber : PT. Cakra Berlian Utama Muara Enim

Pada Tahun 2018

$>$ Gaji,upah dan tunjangan

Jumlah anggaran biaya operasional untuk gaji, upah dan tunjangan sebesar Rp.9.579.517, sedangkan jumlah realisasinya Rp. 9.585.117. Dari data tersebut dapat dilihat selisih sebesar Rp.54.400 yang mana dari hasil tersebut bahwa biaya untuk pembelian pada tahun 2018 sudah terkendali atau favorable.

\section{$>$ Promosi}

Jumlah anggaran biaya operasional untuk promosi berjumlah sebesar Rp.4.410.611 dan jumlah realisasinya sebesar Rp.3.686.696 dapat dilihat selisih sebesar Rp.723.915 yang mana biaya tersebut sudah terkendali karena biaya anggaran lebih besar dari pada realisasinya.

$>$ Perjalanan Dinas Jumlah anggaran biaya operasional untuk perjalanan dinas berjumlah sebesar Rp.871.291dan jumlah realisasinya sebesar Rp.883.399 dapat dilihat selisih sebesar Rp.12.108 yang mana biaya tersebut sudah terkendali karena biaya anggaran lebih besar dari pada realisasinya.

$>$ Penyusutan

Penyusutan Jumlah anggaran biaya operasionalnya sebesar Rp. 254.795 dan jumlah realisasinya sebesar Rp.248.695 dapat dilihat selisih sebesar Rp.6.100 yang mana biaya tersebut sudah terkendali karena biaya anggaran lebih besar dari pada realisasinya.

$>$ Beban Pemeliharaan

Jumlah anggaran biaya operasional untuk beban pemeliharaan berjumlah sebesar Rp.198.987 dan jumlah realisasinya sebesar Rp.190.972 dapat dilihat selisih sebesar Rp.8.015 yang mana biaya tersebut sudah terkendali karena biaya anggaran lebih besar dari pada realisasinya.

$>$ Telekomunikasi

Jumlah anggaran biaya operasional untuk telekomunikasi berjumlah sebesar Rp.499.138 dan jumlah realisasinya sebesar Rp.471.138 dapat dilihat selisih sebesar Rp. 28.000 yang mana biaya tersebut sudah terkendali karena biaya anggaran lebih besar daripada realisasinya.

Lainnya

Jumlah anggaran biaya operasional untuk lainnya berjumlah sebesar Rp.417.911dan jumlah realisasinya sebesar Rp.406.955 dapat dilihat selisih sebesar Rp.10.956 yang mana biaya tersebut sudah terkendali karena biaya anggaran lebih besar daripada realisasinya.

> Gaji, upah dan tunjangan

Jumlah anggaran biaya operasional untuk gaji, upah dan yunjangan berjumlah sebesar Rp.63.923.617 dan jumlah realisasinya sebesar Rp.64.928.869 dapat dilihat selisih sebesar Rp.1.005.252 yang mana biaya tersebut sudah terkendali karena biaya anggaran lebih besar dari pada realisasinya. 
Perjalanan dinas

Jumlah anggaran biaya operasional untuk perjalanan dinas berjumlah sebesar Rp.12.631.871 dan jumlah realisasinya sebesar Rp.12.708.982 dapat dilihat selisih sebesar Rp.77.111 yang mana biaya tersebut sudah terkendali karena biaya anggaran lebih besar dari pada realisasinya.

Sewa

Jumlah anggaran biaya operasional untuk sewa berjumlah sebesar Rp.9.981.196 dan jumlah realisasinya sebesar Rp.9.996.196 dapat dilihat selisih sebesar Rp.15.000 yang mana biaya tersebut sudah terkendali karena biaya anggaran lebih besar dari pada realisasinya.

Telekomunikasi

Jumlah anggaran biaya operasional untuk telekomunikasi berjumlah sebesar Rp.6.241.817 dan jumlah realisasinya sebesar Rp. 5.143.789 dapat dilihat selisih sebesar Rp.1.098.028 yang mana biaya tersebut sudah terkendali karena biaya anggaran lebih besar dari pada realisasinya.

Beban pemeliharaan

Jumlah anggaran biaya operasional untuk beban pemeliharaan berjumlah sebesar Rp.9.531.741 dan jumlah realisasinya sebesar Rp.9.453.500 dapat dilihat selisih sebesar Rp.78.241 yang mana biaya tersebut sudah terkendali karena biaya anggaran lebih besar dari pada realisasinya.

Penyusutan

Jumlah anggaran biaya operasional untuk penyusutan berjumlah sebesar Rp.5.437.178 dan jumlah realisasinya sebesar Rp. 5.347.476 dapat dilihat selisih sebesar Rp.89.702 yang mana biaya tersebut sudah terkendali karena biaya anggaran lebih besar dari pada realisasinya.

Jasa profesional

Jumlah anggaran biaya operasional untuk jasa professional berjumlah sebesar Rp.7.413.144 dan jumlah realisasinya sebesar Rp. 6.462.244 dapat dilihat selisih sebesar Rp.950.900 yang mana biaya tersebut sudah terkendali karena biaya anggaran lebih besar dari pada realisasinya.

Sumbangan

Jumlah anggaran biaya operasional untuk beban sumbangan berjumlah sebesar Rp.2.200.214 dan jumlah realisasinya sebesar Rp. 2.011.124 dapat dilihat selisih sebesar Rp.189.09 yang mana biaya tersebut sudah terkendali karena biaya anggaran lebih besar dari pada realisasinya.

Listrik dan air

Jumlah anggaran biaya operasional untuk listrik dan air berjumlah sebesar Rp.3.375.412 dan jumlah realisasinya sebesar Rp. 3.295.312 dapat dilihat selisih sebesar Rp.80.100 yang mana biaya tersebut sudah terkendali karena biaya anggaran lebih besar dari pada realisasinya.

Rapat dinas

Jumlah anggaran biaya operasional untuk rapat dinas berjumlah sebesar Rp.2.691.148 dan jumlah realisasinya sebesar Rp. 1.469.184 dapat dilihat selisih sebesar Rp.1.221.964 yang mana biaya tersebut sudah terkendali karena biaya anggaran lebih besar dari pada realisasinya.

Diklat dan pengadaan pegawai

Jumlah anggaran biaya operasional untuk pendidikan dan latihan berjumlah sebesar Rp.7.872.601 dan jumlah realisasinya sebesar Rp.7.277.706 dapat dilihat selisih sebesar Rp.594.895 yang mana biaya tersebut sudah terkendali 
karena biaya anggaran lebih besar dari pada realisasinya.

$>$ Asuransi

Jumlah anggaran biaya operasional untuk asuransi berjumlah sebesar Rp.2.127.371 dan jumlah realisasinya sebesar $\mathrm{Rp}$. 1.889 .363 dapat dilihat selisih sebesar Rp.1.939.008 yang mana biaya tersebut sudah terkendali karena biaya anggaran lebih besar daripada realisasinya.

Pembinaan jasmani dan rohani

Jumlah anggaran biaya operasional untuk pembinaan jasmani dan rohani berjumlah sebesar Rp.1.984.259 dan jumlah realisasinya sebesar Rp.1.496.085 dapat dilihat selisih sebesar Rp.488.174 yang mana biaya tersebut sudah terkendali karena biaya anggaran lebih besar dari pada realisasinya.

$>\quad$ Alat tulis kantor

Jumlah anggaran biaya operasional untuk alat tulis kantor berjumlah sebesar Rp.2.116.452 dan jumlah realisasinya sebesar $\mathrm{Rp}$. 2.016.442 dapat dilihat selisih sebesar Rp.100.010 yang mana biaya tersebut sudah terkendali karena biaya anggaran lebih besar dari pada realisasinya.

Keamanan

Jumlah anggaran biaya operasional untuk keamanan berjumlah sebesar Rp.1.815.977 dan jumlah realisasinya sebesar Rp.1.715.977 dapat dilihat selisih sebesar Rp.100.000 yang mana biaya tersebut sudah terkendali karena biaya anggaran lebih besar dari pada realisasinya.

$>\quad$ Penelitian dan pengembangan

Jumlah anggaran biaya operasional untuk penelitian dan pengembangan berjumlah sebesar Rp.1.399.606 dan jumlah realisasinya sebesar Rp. 1.287.406 dapat dilihat selisih sebesar Rp.112.200 yang mana biaya tersebut sudah terkendali karena biaya anggaran lebih besar dari pada realisasinya.

Pajak

Jumlah anggaran biaya operasional untuk pajak berjumlah sebesar Rp.979.597 dan jumlah realisasinya sebesar Rp.859.597 dapat dilihat selisih sebesar Rp.120.000 yang mana biaya tersebut sudah terkendali karena biaya anggaran lebih besar dari pada realisasinya.

Lainnya

Jumlah anggaran biaya operasional untuk lainnya berjumlah sebesar Rp.1.991.571 dan jumlah realisasinya sebesar Rp.1.805.486 dapat dilihat selisih sebesar Rp.186.058 yang mana biaya tersebut sudah terkendali karena biaya anggaran lebih besar dari pada realisasinya.

Tabel Jumalah Anggaran dan Realisasi Biaya Operasional PT. Cakra Berlian Utama Muara Enim Periode 2019 (dalam ribuan rupiah)

\begin{tabular}{|l|r|r|r|}
\hline \multicolumn{1}{|c|}{ Keterangan } & \multicolumn{1}{c|}{$\begin{array}{c}\text { Jumlah } \\
\text { anggaran biaya } \\
\text { operasional }\end{array}$} & $\begin{array}{c}\text { Jumlah } \\
\text { realisasi biaya } \\
\text { operasional }\end{array}$ & $\begin{array}{c}\text { Jumlah } \\
\text { selisih biaya } \\
\text { operasional }\end{array}$ \\
\hline Beban Penjualan & & & \\
Gaji, upah dan tunjuangan & 12.671 .357 & 12.455 .375 & 215.982 \\
Promosi & 13.121 .975 & 12.112 .857 & 1.009 .118 \\
Jasa profesional & 6.156 .846 & 7.456 .964 & 1.300 .118 \\
Perjalanan Dinas & 1.815 .821 & 1.514 .615 & 301.615 \\
Keamanan & 897.734 & 810.833 & 86.901 \\
Penyusutan & 420.105 & 320.050 & 100.055 \\
\hline
\end{tabular}




\begin{tabular}{|c|c|c|c|}
\hline Telekomunikasi & 278.641 & 188.711 & 89.930 \\
\hline Beban Pemeliharaan & 187.510 & 259.466 & 71.956 \\
\hline Sewa & 57.657 & 46.567 & 11.090 \\
\hline Pengakutan dan distribusi & 51.156 .540 & 49.956 .540 & 1.200 .000 \\
\hline Lainnya & 291.500 & 281.499 & 10.001 \\
\hline Beban Adminitrasi & & & \\
\hline Gaji, Upah dan tunjuangan & 96.218 .499 & 97.018 .848 & 800.349 \\
\hline Perjalanan Dinas & 19.581 .009 & 18.567 .099 & 1.013 .910 \\
\hline Sewa & 11.913 .313 & 11.883 .053 & 30.078 \\
\hline Telekumunikasi & 11.214 .904 & 11.114 .209 & 100.001 \\
\hline Beban Pemeliharaan & 12.371 .214 & 11.260 .209 & 1.111 .005 \\
\hline Penyusutan & 8.214 .714 & 8.041 .772 & 199.969 \\
\hline Jasa Profesional & 7.471 .443 & 7.393.649 & 77.794 \\
\hline Sumbangan & 7.014.379 & 6.945 .141 & 69.238 \\
\hline Listrik dan Air & 5.321 .128 & 5.184 .328 & 136.000 \\
\hline Rapat Dinas & 4.156 .431 & 4.065 .531 & 90.900 \\
\hline Diklat dan pengadaan pegawai & 3.998.257 & 3.968 .157 & 30.100 \\
\hline Asuransi & 2.957.175 & 2.975.857 & 18.682 \\
\hline Pembinaan Jasmani \& Rohani & 2.653 .851 & 2.735 .915 & 82.064 \\
\hline Alat Tulis Kantor & 2.458 .416 & 2.568.948 & 110.532 \\
\hline Keamanan & 2.556.341 & 2.465 .349 & 90.892 \\
\hline Penelitian dan Pengembangan & 1.234 .615 & 1.183 .038 & 51.577 \\
\hline Pajak & 1.241 .763 & 1.223 .882 & 17.881 \\
\hline Keselamatan kerja & 391.512 & 329.606 & 61.906 \\
\hline Biaya operasional - program krmitraan & & & \\
\hline dan bina lingkungan & 143.118 & 163.118 & 20.000 \\
\hline pengangkutan & 56.617 & 54.846 & 1.771 \\
\hline Lainnya & 654.718 & 663.871 & 9.153 \\
\hline Total & 288.905 .551 & 285.210 .597 & 8.490 .568 \\
\hline
\end{tabular}

Sumber : PT. Cakra Berlian Utama Muara Enim

\section{Pada Tahun 2019}

Gaji,upah dan tunjangan

Jumlah anggaran biaya operasional untuk gaji, upah dan tunjangan berjumlah sebesar Rp.12.671.357, sedangkan jumlah realisasinya sebesar Rp. 12.455.375 dari data tersebut dapat dilihat selisih sebesar Rp.215.982 yang mana dari hasil tersebut bahwa biaya untuk gaji, upah dan tunjangan pada tahun 2019 sudah terkendali atau favorable.

Promosi

Jumlah anggaran biaya operasional untuk promosi berjumlah sebesar Rp.13.121.975 dan jumlah realisasinya sebesar Rp.12.112.857 dapat dilihat selisih sebesar Rp.1.009.118 yang mana biaya tersebut sudah terkendali karena biaya anggaran lebih besar dari pada realisasinya.

$>\quad$ Perjalanan Dinas

Jumlah anggaran biaya operasional untuk perjalanan dinas berjumlah sebesar Rp. 1.815.821 dan jumlah realisasinya sebesar Rp. 1.514 .615 dapat dilihat selisih sebesar Rp.301.615 yang mana biaya tersebut sudah terkendali karena biaya anggaran lebih besar dari pada realisasinya.

Penyusutan

Penyusutan Jumlah anggaran biaya operasionalnya sebesar Rp.420.105 dan jumlah realisasinya sebesar Rp.320.050 dapat dilihat selisih sebesar Rp.100.055 yang mana biaya tersebut sudah terkendali karena biaya anggaran 
lebih besar dari pada realisasinya.

Telekomunikasi

Jumlah anggaran biaya operasional untuk telekomunikasi berjumlah sebesar Rp. 278.641 dan jumlah realisasinya sebesar Rp.188.711 dapat dilihat selisih sebesar Rp.89.930 yang mana biaya tersebut sudah terkendali karena biaya anggaran lebih besar daripada realisasinya.

Beban Pemeliharaan

Jumlah anggaran biaya operasional untuk beban pemeliharaan berjumlah sebesar Rp.187.510 dan jumlah realisasinya sebesar Rp.259.466 dapat dilihat selisih sebesar Rp.71.956 yang mana biaya tersebut sudah terkendali karena biaya anggaran lebih besar dari pada realisasinya.

Lainnya

Jumlah anggaran biaya operasional untuk lainnya berjumlah sebesar Rp.291.500 dan jumlah realisasinya sebesar Rp. 281.499 dapat dilihat selisih sebesar Rp.10.001yang mana biaya tersebut sudah terkendali karena biaya anggaran lebih besar daripada realisasinya.

Gaji, upah dan tunjangan

Jumlah anggaran biaya operasional untuk gaji, upah dan yunjangan berjumlah sebesar Rp.96.218.499 dan jumlah realisasinya sebesar Rp.97.018.848 dapat dilihat selisih sebesar Rp.800.349 yang mana biaya tersebut sudah terkendali karena biaya anggaran lebih besar dari pada realisasinya.

$>$ Perjalanan dinas

Jumlah anggaran biaya operasional untuk perjalanan dinas berjumlah sebesar Rp.19.581.009 dan jumlah realisasinya sebesar Rp.18.567.099 dapat dilihat selisih sebesar Rp.1.013.910 yang mana biaya tersebut sudah terkendali karena biaya anggaran lebih besar dari pada realisasinya.

Sewa

Jumlah anggaran biaya operasional untuk sewa berjumlah sebesar Rp.11.913.131 dan jumlah realisasinya sebesar Rp. 11.883.053 dapat dilihat selisih sebesar Rp.30.078 yang mana biaya tersebut sudah terkendali karena biaya anggaran lebih besar dari pada realisasinya.

$>$ Telekomunikasi

Jumlah anggaran biaya operasional untuk telekomunikasi berjumlah sebesar Rp.11.214.904 dan jumlah realisasinya sebesar Rp.11.114.903 dapat dilihat selisih sebesar Rp.100.001 yang mana biaya tersebut sudah terkendali karena biaya anggaran lebih besar dari pada realisasinya.

Beban pemeliharaan

Jumlah anggaran biaya operasional untuk beban pemeliharaan berjumlah sebesar Rp.12.371.214 dan jumlah realisasinya sebesar Rp.11.260.209 dapat dilihat selisih sebesar Rp.1.111.005 yang mana biaya tersebut sudah terkendali karena biaya anggaran lebih besar dari pada realisasinya.

Penyusutan

Jumlah anggaran biaya operasional untuk penyusutan berjumlah sebesar Rp.8.241.714 dan jumlah realisasinya sebesar Rp.8.041.772 dapat dilihat selisih sebesar Rp.199.969 yang mana biaya tersebut sudah terkendali karena biaya anggaran lebih besar dari pada realisasinya.

Jasa profesional

Jumlah anggaran biaya operasional untuk jasa professional berjumlah sebesar Rp.7.471.443 dan jumlah realisasinya sebesar Rp.7.393.649 dapat dilihat 
selisih sebesar Rp.77.794 yang mana biaya tersebut sudah terkendali karena biaya anggaran lebih besar dari pada realisasinya.

$>$ Sumbangan

Jumlah anggaran biaya operasional untuk beban sumbangan berjumlah sebesar Rp.7.014.379 dan jumlah realisasinya sebesar Rp. 6.945.141 dapat dilihat selisih sebesar Rp.69.238 yang mana biaya tersebut sudah terkendali karena biaya anggaran lebih besar dari pada realisasinya.

Listrik dan air

Jumlah anggaran biaya operasional untuk listrik dan air berjumlah sebesar Rp.5.321.128 dan jumlah realisasinya sebesar Rp. 5.184.328 dapat dilihat selisih sebesar Rp.136.000 yang mana biaya tersebut sudah terkendali karena biaya anggaran lebih besar dari pada realisasinya.

$>\quad$ Alat tulis kantor

Jumlah anggaran biaya operasional untuk alat tulis kantor berjumlah sebesar Rp.2.458.416 dan jumlah realisasinya sebesar Rp.2.568.948 dapat dilihat selisih sebesar Rp.110.532 yang mana biaya tersebut sudah terkendali karena biaya anggaran lebih besar dari pada realisasinya.

$>$ Rapat dinas

Jumlah anggaran biaya operasional untuk rapat dinas berjumlah sebesar Rp.4.156.431 dan jumlah realisasinya sebesar Rp.4.065.531 dapat dilihat selisih sebesar Rp.90.900 yang mana biaya tersebut sudah terkendali karena biaya anggaran lebih besar dari pada realisasinya.

$>\quad$ Diklat dan pengadaan pegawai

Jumlah anggaran biaya operasional untuk pendidikan dan latihan berjumlah sebesar Rp.3.998.257 dan jumlah realisasinya sebesar Rp.3.968.157 dapat dilihat selisih sebesar Rp.30.100 yang mana biaya tersebut sudah terkendali karena biaya anggaran lebih besar dari pada realisasinya.

Asuransi

Jumlah anggaran biaya operasional untuk asuransi berjumlah sebesar Rp.2.957.175 dan jumlah realisasinya sebesar Rp.2.975.857 dapat dilihat selisih sebesar Rp.18.682 yang mana biaya tersebut sudah terkendali karena biaya anggaran lebih besar daripada realisasinya.

$>\quad$ Pembinaan jasmani dan rohani

Jumlah anggaran biaya operasional untuk pembinaan jasmani dan rohani berjumlah sebesar Rp.2.653.851 dan jumlah realisasinya sebesar Rp.2.735.915 dapat dilihat selisih sebesar Rp.82.064 yang mana biaya tersebut sudah terkendali karena biaya anggaran lebih besar dari pada realisasinya.

Keamanan

Jumlah anggaran biaya operasional untuk keamanan berjumlah sebesar Rp.2.556.241 dan jumlah realisasinya sebesar Rp.2.465.349 dapat dilihat selisih sebesar Rp.90.892 yang mana biaya tersebut sudah terkendali karena biaya anggaran lebih besar dari pada realisasinya.

$>\quad$ Penelitian dan pengembangan

Jumlah anggaran biaya operasional untuk penelitian dan pengembangan berjumlah sebesar Rp.1.234.615 dan jumlah realisasinya sebesar Rp.1.183.038 dapat dilihat selisih sebesar Rp.51.577 yang mana biaya tersebut sudah terkendali karena biaya anggaran lebih besar dari pada realisasinya.

\section{$>$ Pajak}


Jumlah anggaran biaya operasional untuk pajak berjumlah sebesar Rp.1.241.763 dan jumlah realisasinya sebesar Rp.1.223.882 dapat dilihat selisih sebesar Rp.17.881 yang mana biaya tersebut sudah terkendali karena biaya anggaran lebih besar dari pada realisasinya.

$>\quad$ Lainnya

Jumlah anggaran biaya operasional untuk lainnya berjumlah sebesar Rp.654.718 dan jumlah realisasinya sebesar Rp.663.871 dapat dilihat selisih sebesar Rp.9.153 yang mana biaya tersebut sudah terkendali karena biaya anggaran lebih besar dari pada realisasinya.

Berdasarkan data tahun 2018 jumlah biaya operasional Rp.198.893.835 dan jumlah realisasinya Rp.190.306.169 dapat dilihat bahwa tahun 2018 jumlah perbandingan lebih besar 100 yang mana biaya tersebut sudah terkendali. sedangkan tahun 2019 jumlah biaya operasional sebesar Rp.288.905.551 dan jumlah realisasinya Rp.285.210.597 dapat dilihat bahwa tahun 2019 jumlah perbandingan lebih besar 100 yang mana biaya tersebut sudah terkendali.

\section{3) Tingkat Kenaikan Laba}

Setelah dilakukan analisis menggunakan teknik varians terhadap biaya operasional yang dikeluarkan oleh perusahaan yang mana mencari selisih antara jumlah anggaran biaya operasional dengan realisasi jumlah biaya operasional, kemudian dilakukan penilaian dengan teknik kenaikan laba.

Teknik kenaikan laba yaitu teknik yang membandingkan antara biaya operasional dengan pendapatan operasional perusahaan dikali dengan $100 \%$, sehingga terlihat persentase peningkatan atau penurunan laba yang dihasilkan perusahaan dari tahun 2018 sampai dengan 2019.

Teknik ini mengukur tingkat efektivitas pengelolahan perusahaan yang ditunjukkan oleh jumlah keuntungan yang dihasilkan dan menggambarkan kemampuan perusahaan untuk mendapatkan laba melalui semua kemampuan dan sumber uang ada pada perusahaan.

Data yang digunakan dalam penelitian ini adalah laporan laba rugi PT. Cakra Berlian Utama Muara Enim dari tahun 2018 sampai dengan 2019. Adapun rumus yang digunakan sebagi berikut :

$$
\text { BOPO }=\frac{\text { Biaya Operasional }}{\text { Pendapatan }} \times 100 \%
$$

$$
\text { Tahun } \begin{aligned}
2018 & =\frac{190.306 .169}{1.522 .808 .093} \times 100 \% \\
& =12,49 \%
\end{aligned}
$$

$$
\text { Tahun } \begin{aligned}
2019 & =\frac{285.210 .597}{1.551 .524 .990} \times 100 \% \\
& =18,38 \%
\end{aligned}
$$


Tingkat laba yang dimiliki PT. Cakra Berlian Utama Muara Enim mengalami kenaikan, terlihat pada perhitungan diatas berupa selisih anatar laba masa lalu dan sekarang.

Pada tahun 2018 laba yang dihasilkan sebesar 12,49\% dari laba yang dihasilkan, maka dapat disimpulkan laba yang didapatkan baik namun realisasi anggaran biaya operasional tidak melebihi jumlah anggaran biaya operasional sehingga tidak kurangnya pengendalian dalam biaya operasional. Sedangkan tahun 2019 laba yang dihasilkan sebesar 18,38\% hal ini sangatlah baik dengan persentase melebihi dari pada tahun sebelumnya yang mana sebesar $12,49 \%$ dengan selisih sebesar 5,89\%. Laba yang dihasilkan naik daripada tahun sebelumnya namun realisasi biaya operasionalnya lebih besar dari pendapatan yang dihasilkan.

Dari uraian diatas rata-rata pertahun jumlah peningkatan laba yang dihasilkan positif namun dilihat daripada realisasi anggaran maka PT. Cakra Berlian Utama Muara Enim harus lebih mampu memaksimalkan biaya yang harus dikeluarkan supaya laba yang dihasilkan terus meningkat.

\section{H. KESIMPULAN DAN SARAN}

1. Kesimpulan

Berdasarkan analisa yang telah dilakukan, maka kesimpulannya :

1. Berdasarkan analisa yang dilakukan memperlihatkan bahwa terjadinya varians yang favorable, dimana pada tahun 2018 dan 2019 jumlah realisasi biaya operasional selalu lebih kecil dari jumlah yang telah dianggarakan perusahaan.

2. Dapat dilihat pada tahun 2018 biaya operasional Rp.190.306.169 dan pendapatan Rp.1.522.808.093, maka persentase laba usaha yang dihasilkan perusahaan sebesar $12,49 \%$, kemudian pada tahun 2019 biaya operasional Rp.285.210.597 dan pendapatan Rp.1.551.524.990 persentase laba usaha yang didapatkan mengalami peningkatan sebesar 5,89\% menjadi $18,38 \%$.

Dengan demikian pengendalian biaya operasional yang dilakukan PT. Cakra Berlian Utama Muara Enim sudah baik namun harus mampu memaksimalkan pengendalian biaya operasional kembali sehingga laba yang akan dihasilkan lebih mengutungkan lagi.

\section{Saran}

Adapun saran yang dapat penulis berikan pada PT. Cakra Berlian Utama Muara Enim dalam menjaga biaya operasional agar dalam merealisasi biaya operasional perusahaan jumlah realisasi biaya operasional lebih kecil dari jumlah yang telah dianggarankan, sehingga dapat menghasilkan keuntungan bagi perusahaan. Maka disarankan kepada manajemen perusahaan untuk tetap melakukan pengawasan terhadap penggunaan fasilitas perusahaan diluar kegiatan operasional perusahaan.

\section{DAFTAR PUSTAKA}

Ahmad Riahi dan Belkaoui. 2011, Teori akuntansi. Edisi ke 5 buku 2 Jakarta : Salemba Empat.

Bastian Bustomi dan Nurlela. 2010, Akuntansi Biaya. Edisi ke 2 Jakarta : Penerbit Mitra Wacana Media. 
Carter. 2012, Akuntansi Biaya. Edisi 14 Penerbit : Salemba Empat.

Dunia, Firdaus Ahmad dan wasilah. 2012, Akuntansi Biaya, Edisi 3 Jakarta : Salemba Empat.

Islahuzzaman. 2012 Istilah-Istilah Akuntansi dan Auditing. Cetekan Pertama. Jakarta : Penerbit PT. Bumi Aksara.

Mulyadi. 2015, Akuntansi Biaya. Edisi 5 Cetakan Sepuluh Universitas Gajah Mada.

Sanusi, Anwar.2014. Metodologi penelitian. Cetakan keempat. Jakarta : Salemba Empat.

Sugiyono. 2017. Metode Penelitian Pendidikan (Pendekatan Kualitatif, Kuantitatif dan $R \& D)$, CV. Alfabeta Bandung.

Wahyudi Sutopo, dkk. 2014. Anlisis \& Estimasi Biaya. Cetakan ke 1. Surakarta : Penerbit UNS. 